Article

\title{
Five New Taraxerene-Type Triterpenes from the Branch Barks of Davidia involucrata
}

\section{Qing-Wei Tan ${ }^{1,2}$, Ming-An Ouyang ${ }^{1, *}$, Qi-Jian Chen ${ }^{1}$ and Zu-Jian Wu ${ }^{1}$}

1 Key Laboratory of Plant Virology of Fujian Province, Institute of Plant Virology, Fujian Agriculture and Forestry University, Fuzhou 350002, Fujian, China;

E-Mails: tanqingwei@fafu.edu.cn (Q.-W.T.); fafuchenqijian@163.com (Q.-J.C.); wuzujian@126.com (Z.-J.W.)

2 Key Laboratory of Bio-Pesticide and Chemistry-Biology, Ministry of Education, Fujian Agriculture and Forestry University, Fuzhou 350002, Fujian, China

External Editor: Derek J. McPhee

* Author to whom correspondence should be addressed; E-Mail: maouyang@hqu.edu.cn; Tel.: +86-59-183-789-365.

Received: 8 October 2014; in revised form: 27 October 2014 / Accepted: 28 October 2014 / Published: 30 October 2014

\begin{abstract}
Five new taraxerene-type triterpenes, 2-nor-D-friedoolean-14-en-28-ol (1), 2-nor-D-friedoolean-14-en-3 $\alpha, 28$-diol (2), 6 $\alpha$-hydroxy-2-nor-D-friedoolean-14-en-3,21-dione

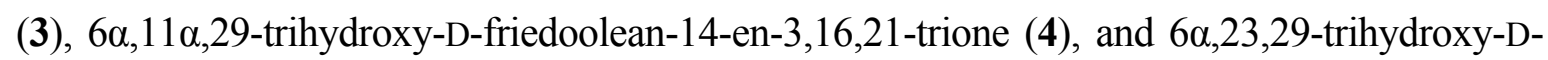
friedoolean-14-en-3,16,21-trione (5), were isolated from the $\mathrm{MeOH}$ extract of the branch barks of Davidia involucrata, together with five known compounds. Their structures were elucidated by means of various spectroscopic analyses. Five of the identified compounds showed moderate cytotoxicities against the cell proliferation of SGC-7901, MCF-7, and BEL-7404.
\end{abstract}

Keywords: Davidia involucrata; Nyssaceae; taraxerene; triterpenoid

\section{Introduction}

Davidia involucrata Baill., an ornamental tree known as the Chinese dove tree or handkerchief tree, is the only species in genus Davidia. D. involucrata is a relic deciduous tree species of the Tertiary 
period with important ecological, scientific and horticultural values [1-3]. An initial and the only report of study on chemical components of D. involucrata besides our program appeared in 1989, which revealed the presence of sterols, tannins and triterpenes [4]. The branch barks of D. involucrata have been intensively studied in our previous work and were found containing diverse constituents including flavonoids, alkaloids, lignans, and phenols, among which were three alkaloids including vicosamide, strictosidinic acid and puimiloside, which were proposed to be the intermediate precursors between strictosamide and camptothecin [5-12]. Moreover, we have recently reported the identification of two novel 2-nor-ursane triterpenes having a unique five-membered A-ring from the water insoluble fraction of the branch barks of D. involucrata [13].

Our continuing work led to the isolation of another five novel triterpenoids, namely davinvolunols A-B (1-2) and davinvolunones A-C (3-5), together with a known taraxerene triterpene, myricadiol

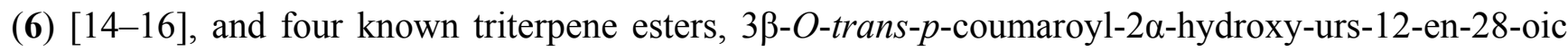

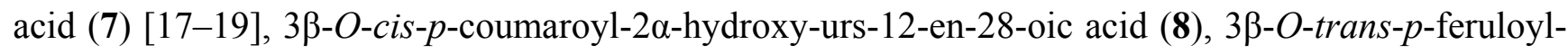
$2 \alpha$-hydroxy-urs-12-en-28-oic acid (9), 3 $\beta$-O-cis- $p$-feruloyl-2 $\alpha$-hydroxy-urs-12-en-28-oic acid (10) [19] (Figure 1). Compounds 1-3 feature a contracted five-membered A-ring, whereas 4-5 are highly oxidized. The novel structures were unequivocally determined by extensive spectroscopic analysis and comparison with literature data. We herein report in this paper the structure elucidation of the new triterpenes, as well as the in vitro cytotoxic activities against three tumor cell lines (SGC-7901, MCF-7 and BEL-7404) of the isolated compounds.

Figure 1. Chemical structures of compounds isolated from the branch barks of Davidia involucrata.
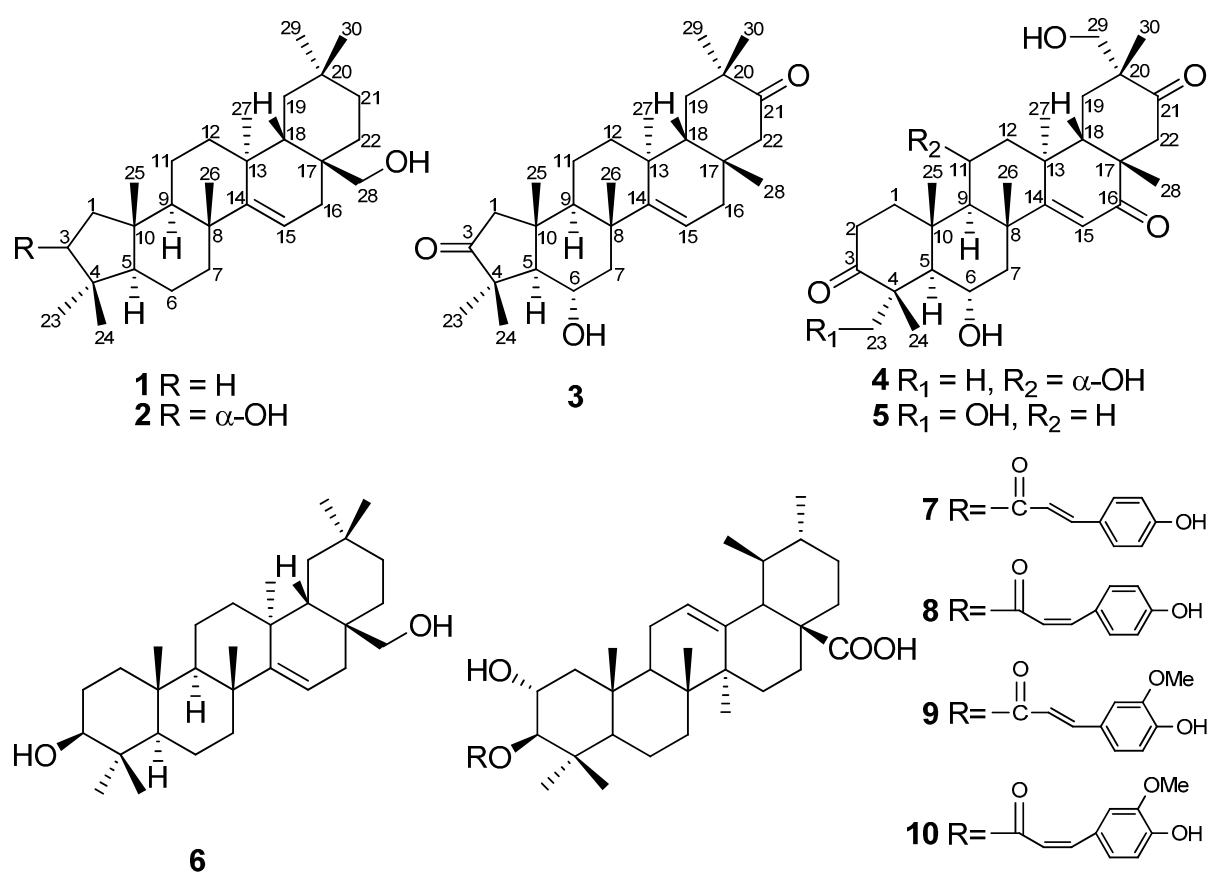

\section{Results and Discussion}

Compound 1, a white amorphous powder, had a molecular formula of $\mathrm{C}_{29} \mathrm{H}_{48} \mathrm{O}$ as determined by HR-TOF-MS at $m / z=435.3596[\mathrm{M}+\mathrm{Na}]^{+}$(calcd for $\mathrm{C}_{29} \mathrm{H}_{48} \mathrm{ONa}, 435.3603$ ). The IR spectrum 
exhibited absorption bands due to hydroxyl $\left(3560 \mathrm{~cm}^{-1}\right)$ and olefinic $\left(1640 \mathrm{~cm}^{-1}\right)$ groups. Observed in the ${ }^{1} \mathrm{H}-\mathrm{NMR}\left(500 \mathrm{MHz}, \mathrm{CDCl}_{3}\right.$ and $\mathrm{CD}_{3} \mathrm{OD}$ ) spectrum were signals for seven tertiary methyl groups at $\delta_{\mathrm{H}} 0.87,0.94,0.94,1.05,1.07,1.08$ and $1.22(\mathrm{~s}$, each $3 \mathrm{H})$, while resonances at $\delta_{\mathrm{H}} 3.10$ and $3.23(\mathrm{~d}$, $J=10.9 \mathrm{~Hz}$, each $1 \mathrm{H}$ ) were attributed to proton signals attached to an oxygenated methylene carbon. In addition, one olefinic proton at $\delta_{\mathrm{H}} 5.51(\mathrm{dd}, J=8.2,3.1 \mathrm{~Hz}, 1 \mathrm{H})$ of a trisubstituted double bond, coupled with the protons of a methylene at $\delta_{\mathrm{H}} 1.68(\mathrm{dd}, J=15.2,3.1 \mathrm{~Hz}, 1 \mathrm{H})$ and $2.13(\mathrm{dd}, J=15.2$, $8.2 \mathrm{~Hz}, 1 \mathrm{H})$ as deduced from their coupling constants, was recognized in the ${ }^{1} \mathrm{H}-\mathrm{NMR}$ spectrum. The ${ }^{13} \mathrm{C}-\mathrm{NMR}\left(125 \mathrm{MHz}, \mathrm{CDCl}_{3}\right.$ and $\left.\mathrm{CD}_{3} \mathrm{OD}\right)$ spectrum of $\mathbf{1}$ showed 29 carbon signals, which were classified from DEPT and HSQC data as seven methyls, ten methylenes, three methines, six quaternary carbons, one oxygen-bearing secondary carbon and a trisubstituted double bond. One of the six degrees of unsaturation came from a trisubstituted double bond at $\delta_{\mathrm{C}} 116.0$ and 158.5, and the remaining five degrees of unsaturation were therefore indicative of a pentacyclic skeleton. The characteristics of NMR data of compound 1 were comparable to those of myricadiol (6) [13]. Comparison of the MS, 1D- and 2D-NMR data of 1 with those of 6 revealed that they both shared the same $\mathrm{B} / \mathrm{C} / \mathrm{D} / \mathrm{E}$ rings, indicating that 1 might bear a contracted five-membered A-ring. This inference was confirmed by the HMBC and ROESY experiments. The key HMBC correlations (Figure 2) from $\mathrm{H}_{3}-23\left(\delta_{\mathrm{H}} 1.22, \mathrm{~s}, 3 \mathrm{H}\right)$ and $\mathrm{H}_{3}-24\left(\delta_{\mathrm{H}} 0.94, \mathrm{~s}, 3 \mathrm{H}\right)$ to $\mathrm{C}-3\left(\delta_{\mathrm{C}} 29.8\right), \mathrm{C}-4\left(\delta_{\mathrm{C}} 47.5\right)$ and $\mathrm{C}-5\left(\delta_{\mathrm{C}} 55.7\right)$ enabled the establishment of an unusual five-membered A-ring. The observed ROESY cross-peaks (Figure 3) of $\mathrm{H}_{3}-24 / \mathrm{H}_{3}-25, \mathrm{H}_{3}-25 / \mathrm{H}-26$, and $\mathrm{H}-18 / \mathrm{H}-28$ indicated that they were on the same side of the molecule, and were arbitrarily assigned as $\beta$-oriented. As a consequence, the ROESY correlations of $\mathrm{H}_{3}-23 / \mathrm{H}-5, \mathrm{H}-5 / \mathrm{H}-9$, and $\mathrm{H}-9 / \mathrm{H}_{3}-27$ revealed that they were $\alpha$-configured. Hence, the structure of compound 1 was determined to be 2-nor-D-friedoolean-14-en-28-ol, and this substance has been accorded the trivial name davinvolunol A.

Figure 2. Key HMBC $(\mathrm{H} \rightarrow \mathrm{C})$ correlations of compounds $\mathbf{1}-\mathbf{5}$.

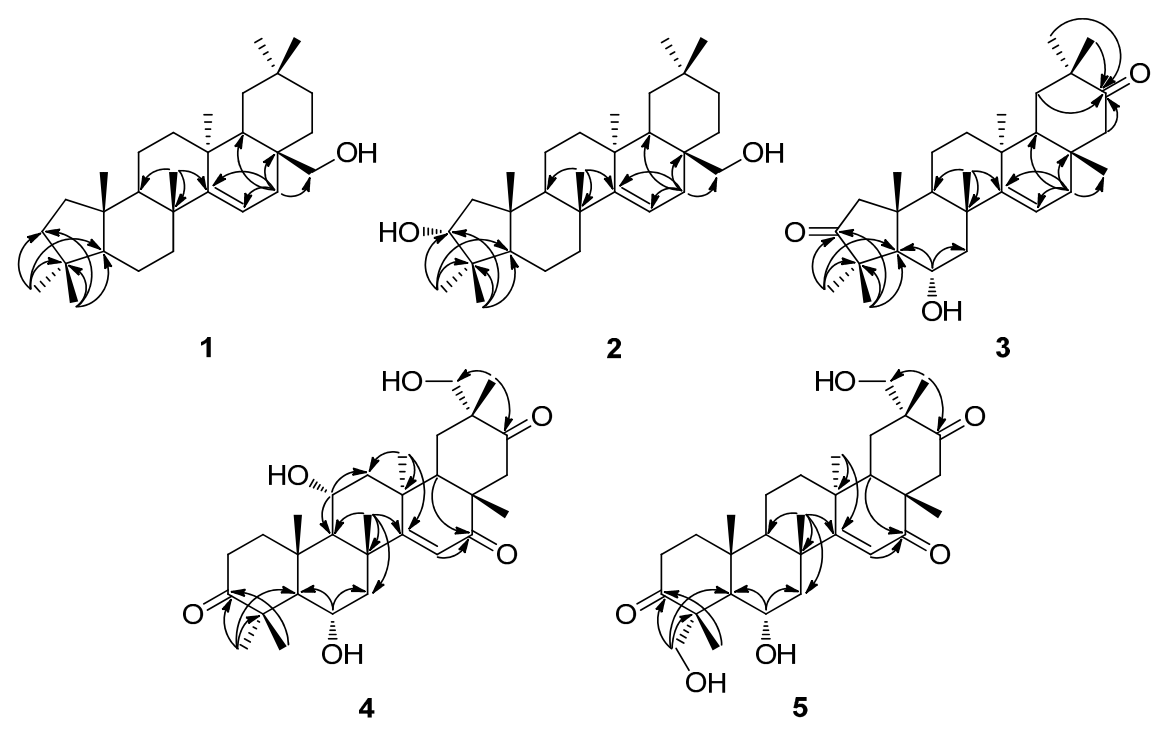

Compound 2 was isolated as a white amorphous solid. It was assigned to have a molecular formula of $\mathrm{C}_{29} \mathrm{H}_{48} \mathrm{O}_{2}$ by HR-TOF-MS at $m / z=451.3546[\mathrm{M}+\mathrm{Na}]^{+}$(calcd for $\mathrm{C}_{29} \mathrm{H}_{48} \mathrm{O}_{2} \mathrm{Na}, 451.3552$ ). The ${ }^{1} \mathrm{H}$ and ${ }^{13} \mathrm{C}$-NMR spectra of $\mathbf{2}$ were highly similar to those of $\mathbf{1}$ except for the absence of methylene proton 
signals at $\delta_{\mathrm{H}} 2.01$ and $2.25(\mathrm{~m}$, each $1 \mathrm{H})$ with the presence of an additional oxymethine proton signal at $\delta_{\mathrm{H}} 3.18(\mathrm{dd}, J=9.8,6.8 \mathrm{~Hz}, 1 \mathrm{H})$ instead, suggesting that a hydroxyl group was attached to C-3. This was confirmed by the key HMBC correlations (Figure 2) from $\mathrm{H}_{3}-23\left(\delta_{\mathrm{H}} 1.05, \mathrm{~s}, 3 \mathrm{H}\right)$ and $\mathrm{H}_{3}-24$ $\left(\delta_{\mathrm{H}} 0.91, \mathrm{~s}, 3 \mathrm{H}\right)$ to $\mathrm{C}-3\left(\delta_{\mathrm{C}} 77.3\right)$. The ROESY correlations (Figure 3 ) of $\mathrm{H}-3 / \mathrm{H}_{3}-24, \mathrm{H}_{3}-25$ implied that $\mathrm{H}-3$ was $\alpha$-orientated, and thus $3-\mathrm{OH}$ was in $\beta$-orientation. Other observed ROESY effects indicated the relative configuration of the remaining part of the molecule of 2 was identical with that of $\mathbf{1}$. Thus, the structure of compound 2 (davinvolunol B) was elucidated as 2-nor-D-friedoolean-14-en-3 $\alpha, 28$-diol.

Figure 3. Key ROESY $(\mathrm{H} \leftrightarrow \mathrm{C})$ correlations of compounds 1-5.
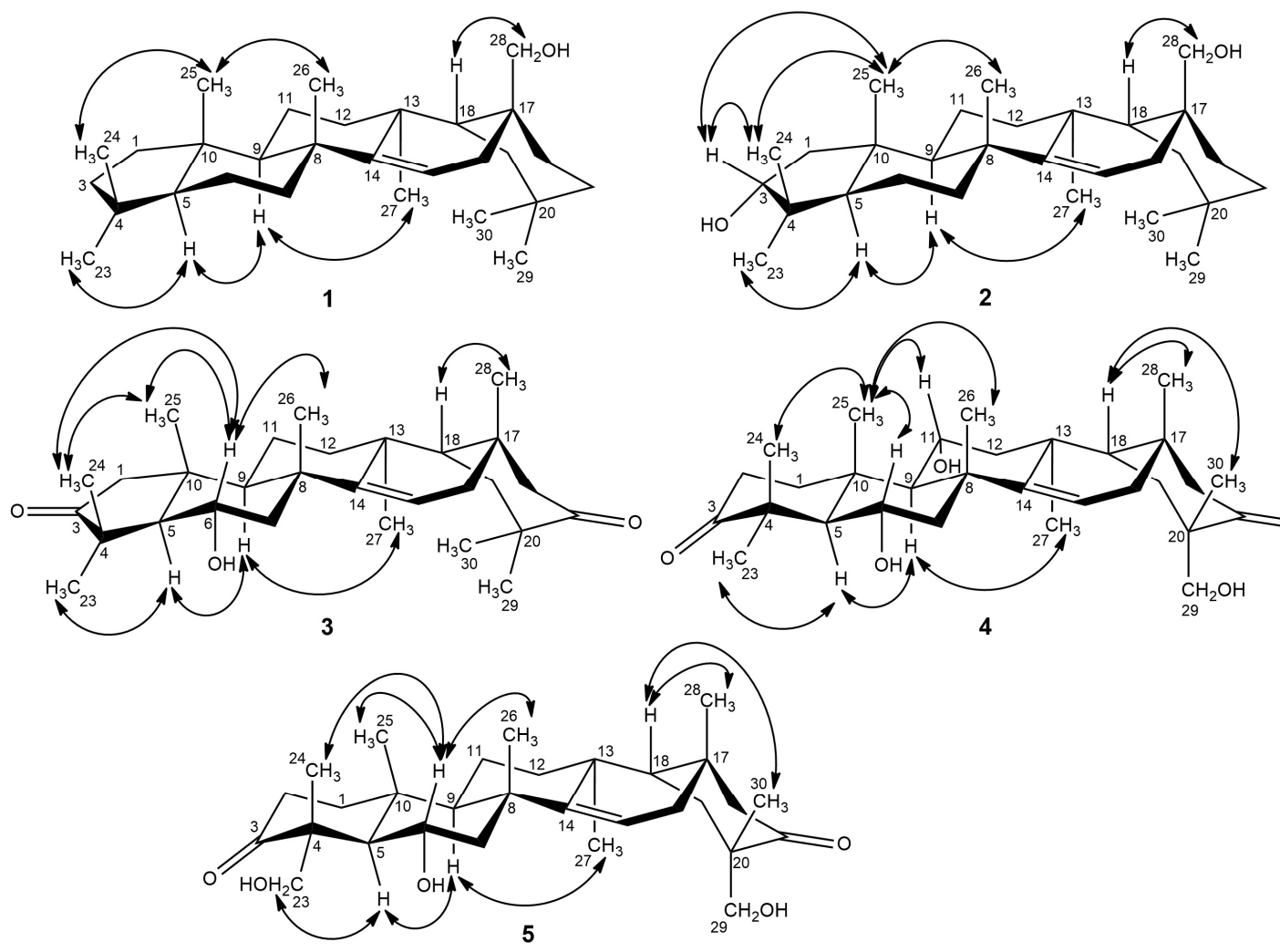

Compound 3, a white amorphous solid, presented a molecular formula of $\mathrm{C}_{29} \mathrm{H}_{44} \mathrm{O}_{3}$, as determined by HR-TOF-MS at $m / z=463.3180[\mathrm{M}+\mathrm{Na}]^{+}$(calcd for $\mathrm{C}_{29} \mathrm{H}_{44} \mathrm{O}_{3} \mathrm{Na}, 463.3188$ ) with eight double-bond equivalents. The IR spectrum revealed the presence of hydroxyl $\left(3437 \mathrm{~cm}^{-1}\right)$, carbonyl $\left(1726 \mathrm{~cm}^{-1}\right)$ and olefinic $\left(1635 \mathrm{~cm}^{-1}\right)$ groups. The ${ }^{1} \mathrm{H}-\mathrm{NMR}\left(400 \mathrm{MHz}, \mathrm{CDCl}_{3}\right)$ spectrum showed eight tertiary methyls at $\delta_{\mathrm{H}} 0.78,0.82,1.02,1.05,1.06,1.11,1.29$ and 1.32 (s, each $\left.3 \mathrm{H}\right)$, and a characteristic olefinic proton signal at $\delta_{\mathrm{H}} 5.60(\mathrm{dd}, J=8.1,2.9 \mathrm{~Hz}, 1 \mathrm{H})$ coupled with the protons of a methylene at $\delta_{\mathrm{H}} 1.79$ $(\mathrm{dd}, J=14.5,8.1 \mathrm{~Hz}, 1 \mathrm{H})$ and $2.05(\mathrm{dd}, J=14.5,2.9 \mathrm{~Hz}, 1 \mathrm{H})$, as deduced from their coupling constants, indicative of the same D-friedoolean-14-en skeleton of $\mathbf{3}$ as compounds $\mathbf{1}$ and $\mathbf{2}$. In addition, an oxygenated methylene at $\delta_{\mathrm{H}} 3.91$ (ddd, $\left.J=15.0,10.9,4.1 \mathrm{~Hz}, 1 \mathrm{H}\right)$ coupled with the protons of a methylene at $\delta_{\mathrm{H}} 1.38(\mathrm{t}, J=10.9 \mathrm{~Hz}, 1 \mathrm{H})$ and $2.28(\mathrm{dd}, J=10.9,4.1 \mathrm{~Hz}, 1 \mathrm{H})$ was observed in the ${ }^{1} \mathrm{H}-\mathrm{NMR}$ spectrum of 3 . The ${ }^{13} \mathrm{C}-\mathrm{NMR}\left(100 \mathrm{MHz}, \mathrm{CDCl}_{3}\right)$ spectrum, along with HSQC and DEPT data, resolved 29 carbons that came from eight methyls, seven methylenes, three methines, six quaternary carbons, an oxygenated secondary carbon, two keto carbonyls and a trisubstituted double bond. The HMBC correlations (Figure 2) from $\mathrm{H}_{3}-23\left(\delta_{\mathrm{H}} 1.29, \mathrm{~s}, 3 \mathrm{H}\right)$ and $\mathrm{H}_{3}-24\left(\delta_{\mathrm{H}} 1.32, \mathrm{~s}, 3 \mathrm{H}\right)$ to 
C-3 ( $\left.\delta_{\mathrm{C}} 219.7\right)$ rationalized the existence of a keto group at C-3, while another keto group was assigned to $\mathrm{C}-21$ as deduced from the HMBC correlations from $\mathrm{H}_{3}-29\left(\delta_{\mathrm{H}} 1.06, \mathrm{~s}, 3 \mathrm{H}\right)$ and $\mathrm{H}_{3}-30\left(\delta_{\mathrm{H}} 1.05, \mathrm{~s}\right.$, $3 \mathrm{H})$ to $\mathrm{C}-21\left(\delta_{\mathrm{C}} 219.7\right)$. An $\mathrm{OH}$ group was attached at $\mathrm{C}-6$ as deduced from the key HMBC correlations of H-6 $(\delta \mathrm{H} 3.91$, ddd, $J=15.0,10.9,4.1 \mathrm{~Hz}, 1 \mathrm{H})$ to $\mathrm{C}-5\left(\delta_{\mathrm{C}} 58.8\right)$ and $\mathrm{C}-7\left(\delta_{\mathrm{C}} 50.4\right)$, as well as the observation of an AMX spin system of $\mathrm{H}-5\left(\delta_{\mathrm{H}} 1.61, \mathrm{~d}, J=10.9 \mathrm{~Hz}, 1 \mathrm{H}\right), \mathrm{H}-6\left(\delta_{\mathrm{H}} 3.91\right.$, $\mathrm{ddd}, J=15.0,10.9,4.1 \mathrm{~Hz}, 1 \mathrm{H}), \mathrm{H}-7 \mathrm{a}\left(\delta_{\mathrm{H}} 1.38, \mathrm{t}, J=10.9 \mathrm{~Hz}, 1 \mathrm{H}\right)$ and $\mathrm{H}-7 \mathrm{~b}\left(\delta_{\mathrm{H}} 2.28, \mathrm{dd}, J=10.9\right.$, $4.1 \mathrm{~Hz}, 1 \mathrm{H})$ in the ${ }^{1} \mathrm{H}-\mathrm{NMR}$ spectrum. A $\Delta^{14}$ double bond was determined by the HMBC correlations from $\mathrm{H}_{3}-26\left(\delta_{\mathrm{H}} 1.11, \mathrm{~s}, 3 \mathrm{H}\right)$ to $\mathrm{C}-14\left(\delta_{\mathrm{c}} 157.3\right)$, and from $\mathrm{H}-16 \mathrm{a}\left(\delta_{\mathrm{H}} 1.79, \mathrm{dd}, J=14.5,8.1 \mathrm{~Hz}\right)$ and $\mathrm{H}-16 \mathrm{~b}\left(\delta_{\mathrm{H}} 2.05, \mathrm{dd}, J=14.5,2.9 \mathrm{~Hz}, 1 \mathrm{H}\right)$ to $\mathrm{C}-14\left(\delta_{\mathrm{C}} 157.3\right)$ and $\mathrm{C}-15\left(\delta_{\mathrm{C}} 116.5\right)$. The relative stereochemistry of $\mathbf{3}$ was established by the ROESY spectrum. The ROESY correlations (Figure 3) of $\mathrm{H}-6 / \mathrm{H}_{3}-24, \mathrm{H}_{3}-25, \mathrm{H}_{3}-26$ and $\mathrm{H}-18 / \mathrm{H}_{3}-28, \mathrm{H}_{3}-30$ implied that $\mathrm{H}-6, \mathrm{H}_{3}-24, \mathrm{H}_{3}-25, \mathrm{H}_{3}-26, \mathrm{H}_{3}-28, \mathrm{H}_{3}-30$ were cofacial and placed in $\beta$-orientation, and thus indicated the $\alpha$-orientation of the hydroxyl group at C-6. The structure of compound $\mathbf{3}$ was therefore determined as $6 \alpha$-hydroxy-2-nor-D-friedoolean-14-en3,21-dione and named davinvolunone A.

Compound 4 was obtained as a white amorphous powder. Its molecular formula was deduced to be $\mathrm{C}_{30} \mathrm{H}_{44} \mathrm{O}_{6}$ by the HR-TOF-MS at $m / z 523.3030[\mathrm{M}+\mathrm{Na}]^{+}$(calcd for $\mathrm{C}_{30} \mathrm{H}_{44} \mathrm{O}_{6} \mathrm{Na}, 523.3036$ ). The IR spectrum exhibited the presence of hydroxyl $\left(3500 \mathrm{~cm}^{-1}\right)$, carbonyl $\left(1700 \mathrm{~cm}^{-1}\right)$ and conjugated carbonyl $\left(1610 \mathrm{~cm}^{-1}\right)$ functional groups. The ${ }^{1} \mathrm{H}-\mathrm{NMR}$ spectrum of compound 4 showed the presence of proton signals for seven tertiary methyls at $\delta_{\mathrm{H}} 0.98,1.06,1.07,1.22,1.26,1.35$ and 1.36 (s, each $3 \mathrm{H})$, and resonances at $\delta_{\mathrm{H}} 3.98(\mathrm{ddd}, J=15.2,11.1,4.2 \mathrm{~Hz}, 1 \mathrm{H})$ and $\delta_{\mathrm{H}} 4.28(\mathrm{t}, J=7.0 \mathrm{~Hz}, 1 \mathrm{H})$ attributed to proton attached to two oxygenated methine carbons, as well as signals of two protons at $\delta_{\mathrm{H}} 3.26$ and $3.71(\mathrm{~d}, J=10.3 \mathrm{~Hz}$, each $1 \mathrm{H})$ attached to an oxygenated methylene carbon. In addition, an olefinic proton signal at $\delta_{\mathrm{H}} 5.96(\mathrm{br} . \mathrm{s}, 1 \mathrm{H})$ was observed in the ${ }^{1} \mathrm{H}-\mathrm{NMR}$ spectrum. The ${ }^{13} \mathrm{C}-\mathrm{NMR}$ (400 MHz, CD ${ }_{3} \mathrm{OD}$ ) including DEPT experiments showed that four of the nine degrees of unsaturation came from one trisubstituted double bond at $\delta_{\mathrm{C}} 118.8$ and 177.9, and three keto carbonyls at $\delta_{\mathrm{C}} 206.3$, 219.9 and 222.5. The remaining five degrees of unsaturation were therefore indicative of a pentacyclic skeleton. A $\Delta^{14}$ double bond was determined by the key HMBC correlations (Figure 2 ) from $\mathrm{H}_{3}-26\left(\delta_{\mathrm{H}}\right.$ $1.26, \mathrm{~s}, 3 \mathrm{H})$ and $\mathrm{H}_{3}-27\left(\delta_{\mathrm{H}} 1.22, \mathrm{~s}, 3 \mathrm{H}\right)$ to $\mathrm{C}-14\left(\delta_{\mathrm{C}} 177.9\right)$. Key HMBC correlations from the olefinic proton at $\delta_{\mathrm{H}} 5.96$ (br. s, $1 \mathrm{H}$ ) to a carbonyl at $\delta_{\mathrm{C}} 206.3$ indicated that one keto group was placed at C-16. Another two keto groups were assigned to $\mathrm{C}-3$ and $\mathrm{C}-21$, which was confirmed by the observed key HMBC correlations from $\mathrm{H}_{3}-23\left(\delta_{\mathrm{H}} 1.35, \mathrm{~s}, 3 \mathrm{H}\right)$ and $\mathrm{H}_{3}-24\left(\delta_{\mathrm{H}} 1.36, \mathrm{~s}, 3 \mathrm{H}\right)$ to $\mathrm{C}-3\left(\delta_{\mathrm{c}} 222.5\right)$, and correlations from $\mathrm{H}_{3}-30\left(\delta_{\mathrm{H}} 1.06, \mathrm{~s}, 3 \mathrm{H}\right)$ to $\mathrm{C}-21\left(\delta_{\mathrm{C}} 219.9\right)$. Moreover, three hydroxyls were attached to $\mathrm{C}-6, \mathrm{C}-11$ and $\mathrm{C}-29$ respectively, which was supported by the key HMBC correlations observed from H-5 $\left(\delta_{\mathrm{H}} 1.78, \mathrm{~d}, J=11.1 \mathrm{~Hz}, 1 \mathrm{H}\right), \mathrm{H}-7 \mathrm{a}\left(\delta_{\mathrm{H}} 1.49, \mathrm{t}, J=11.1 \mathrm{~Hz}, 1 \mathrm{H}\right)$ and $\mathrm{H}-7 \mathrm{~b}\left(\delta_{\mathrm{H}} 2.30\right.$, dd, $J=11.1,4.2 \mathrm{~Hz}, 1 \mathrm{H})$ to $\mathrm{C}-6\left(\delta_{\mathrm{C}} 67.5\right)$, from $\mathrm{H}-9\left(\delta_{\mathrm{H}} 1.60, \mathrm{~d}, J=7.0 \mathrm{~Hz}, 1 \mathrm{H}\right)$ and $\mathrm{H}-12 \mathrm{a}\left(\delta_{\mathrm{H}} 1.98, \mathrm{~d}\right.$, $J=14.5 \mathrm{~Hz}, 1 \mathrm{H})$ to $\mathrm{C}-11\left(\delta_{\mathrm{C}} 65.9\right)$, and from $\mathrm{H}_{3}-30\left(\delta_{\mathrm{H}} 1.06, \mathrm{~s}, 3 \mathrm{H}\right)$ to C-29 $\left(\delta_{\mathrm{C}} 71.2\right)$. ROESY experiment was undertaken to establish the relative configuration of 4 . The significant ROESY correlations (Figure 3) of $\mathrm{H}-11 / \mathrm{H}_{3}-25, \mathrm{H}-6 / \mathrm{H}_{3}-24, \mathrm{H}_{3}-25$ and $\mathrm{H}_{3}-26, \mathrm{H}-18 / \mathrm{H}_{3}-28$ and $\mathrm{H}_{3}-30$ indicated that they were on the same side of the molecule, and were assigned as $\beta$-oriented. As a consequence, the ROESY correlations of $\mathrm{H}_{3}-23 / \mathrm{H}-5, \mathrm{H}-5 / \mathrm{H}-9$ and $\mathrm{H}-9 / \mathrm{H}_{3}-27$ revealed that they were $\alpha$-configured. Thus, the structure of compound 4 (davinvolunone B) was determined as $6 \alpha, 11 \alpha, 29$-trihydroxy-Dfriedoolean-14-en-3,16,21-trione. 
Compound 5, obtained as a white amorphous powder, was assigned to have a molecular formula of $\mathrm{C}_{30} \mathrm{H}_{44} \mathrm{O}_{6}$ by HR-TOF-MS at $m / z=523.3030[\mathrm{M}+\mathrm{Na}]^{+}$(calcd for $\mathrm{C}_{30} \mathrm{H}_{44} \mathrm{O}_{6} \mathrm{Na}, 523.3036$ ), which was an isomer of 4 . The NMR data of 5 were comparable to those of 4 . Observed in the ${ }^{1} \mathrm{H}-\mathrm{NMR}$ spectra was the absence of proton signal of an oxymethine at $\mathrm{H}-11\left(\delta_{\mathrm{H}} 4.28, \mathrm{t}, J=7.0 \mathrm{~Hz}, 1 \mathrm{H}\right)$, with the appearance of an additional oxygenated methylene proton resonances at $\delta_{\mathrm{H}} 3.58(\mathrm{~d}, J=10.2 \mathrm{~Hz}, 1 \mathrm{H})$ and $3.80(\mathrm{~d}, J=10.2 \mathrm{~Hz}, 1 \mathrm{H})$ in the ${ }^{1} \mathrm{H}-\mathrm{NMR}$ spectra of 5. Correspondingly, an oxymethine carbon at $\delta_{\mathrm{C}} 65.9(\mathrm{C}-11)$ was absent with the presence of an oxygenated secondary carbon at $\delta_{\mathrm{C}} 72.5$ in the ${ }^{13} \mathrm{C}-\mathrm{NMR}$ spectra of 5. The HMBC correlations from $\mathrm{H}-23 \mathrm{a}\left(\delta_{\mathrm{H}} 3.58, \mathrm{~d}, J=10.2 \mathrm{~Hz}, 1 \mathrm{H}\right)$ and $\mathrm{H}-23 \mathrm{~b}$ $\left(\delta_{\mathrm{H}} 3.80, \mathrm{~d}, J=10.2 \mathrm{~Hz}, 1 \mathrm{H}\right)$ to $\mathrm{C}-3\left(\delta_{\mathrm{C}} 220.9\right), \mathrm{C}-4\left(\delta_{\mathrm{C}} 54.3\right)$ and $\mathrm{C}-5\left(\delta_{\mathrm{C}} 54.2\right)$ indicated that a hydroxyl group was attached to $\mathrm{C}-23$, which was also confirmed by the key ROESY correlations (Figure 3) of H-23/H-5, as well as the downfield shifted carbon resonance of C-4, as compared with those of compound 4. Analysis of the ROESY spectrum suggested the relative configuration of the remainder of the molecule of 5 was identical with that of $\mathbf{4}$. Compound 5 (davinvolunone $\mathrm{C}$ ) was therefore determined as 6 $\alpha, 23,29$-trihydroxy-D-friedoolean-14-en-3,16,21-trione.

The novel compounds, namely davinvolunols A-B (1-2) and davinvolunones A-C (3-5), are all taraxerene-type triterpenoids with a D-friedoolean-14-en skeleton. To the best of our knowledge, compounds 1-3, as well as previously reported two ursane triterpenes, davinvolunic acid A and B from the same plant [13], are the first reported 2-nor pentacyclic triterpenoids with 29 carbons and a five-membered A-ring. The results provided important, evolutionary and chemotaxonomic knowledge of monotypic genus Davidia.

The isolated triterpenoids were evaluated for cytotoxic activities against SGC-7901 human gastric cancer cells, MCF-7 human breast cancer cells and BEL-7404 human hepatoma cells. The cytotoxicities were summarized in Table 1. Among the pure triterpenoids isolated from Davidia involucrata, compounds 3-5, 7 and 9 showed moderate cytotoxic activities against all three cell lines. Moreover, davinvolunone B (4) exhibited the most potent cytotoxicities towards SGC-7901, MCF-7, and BEL-7404 cancer cells with $\mathrm{IC}_{50}$ value of $30.57 \pm 1.63,41.34 \pm 1.24$, and $37.29 \pm 1.64 \mu \mathrm{M}$, respectively.

Table 1. Cytotoxicities of compounds 1-7 and 9 against three human tumor cell lines $\left(\mathrm{IC}_{50}, \mu \mathrm{M}\right)$.

\begin{tabular}{cccc}
\hline \multirow{2}{*}{ Compounds } & \multicolumn{3}{c}{ Cell Lines } \\
\cline { 2 - 4 } & SGC-7901 & MCF-7 & BEL-7404 \\
\hline $\mathbf{1}$ & $>100$ & $>100$ & $>100$ \\
$\mathbf{2}$ & $>100$ & $>100$ & $>100$ \\
$\mathbf{3}$ & $58.23 \pm 2.36$ & $65.35 \pm 3.12$ & $70.26 \pm 4.21$ \\
$\mathbf{4}$ & $30.57 \pm 1.63$ & $41.34 \pm 1.24$ & $37.29 \pm 1.64$ \\
$\mathbf{5}$ & $32.22 \pm 1.22$ & $42.54 \pm 1.67$ & $39.26 \pm 1.14$ \\
$\mathbf{6}$ & $>100$ & $>100$ & $>100$ \\
$\mathbf{7}$ & $35.47 \pm 1.55$ & $55.24 \pm 2.28$ & $53.82 \pm 2.11$ \\
$\mathbf{9}$ & $37.65 \pm 1.85$ & $58.93 \pm 2.58$ & $54.77 \pm 2.05$ \\
Doxorubicin & $0.19 \pm 0.032$ & $0.08 \pm 0.007$ & $0.12 \pm 0.011$ \\
\hline
\end{tabular}




\section{Experimental Section}

\subsection{General}

Optical rotations were measured with a Jasco DIP-180 digital polarimeter. IR spectra were recorded with a Perkin-Elmer 1750 FT-IR spectrometer in KBr discs. High-resolution mass spectra were recorded on an IonSpec 4.7 Tesla FTMS instrument. The NMR spectra were obtained by using a Bruker AV-400 or a DRX-500 spectrometer. Semipreparative HPLC was performed with an Elite P230 pump equipped with a Schambeck SFD GmbH RI2000 detector and a YMC-Pack SIL column $(250 \times 10 \mathrm{~mm}, 5 \mu \mathrm{m})$. Sephadex LH-20 (25-100 $\mu$ m, Pharmacia Fine Chemicals, Uppsala, Sweden), Silica gel (200-300 mesh) and Silica gel H (Qingdao Oceanic Chemical Co., Qingdao, China) were used for column chromatography. Thin-layer chromatography was performed on TLC plates (H, Qingdao Oceanic Chemical Co.), with compounds visualized by spraying with $5 \%(\mathrm{v} / \mathrm{v}) \mathrm{H}_{2} \mathrm{SO}_{4}$ in alcohol solution, followed by heating.

\subsection{Plant Material}

The branch barks of $D$. involucrata were collected from Shennongjia Forest Region of Hubei province, P. R. China in 2002. The plant was authenticated by Prof. Y. P. Yang. A voucher specimen (No. 12245) is deposited in the Herbarium of Kunming Institute of Botany, Chinese Academy of Sciences, Kunming, China.

\subsection{Extraction and Isolation}

The air-dried branch barks of the plant $(10 \mathrm{~kg})$ were extracted with $\mathrm{MeOH}(2 \times 10 \mathrm{~L})$ at room temperature to give $600 \mathrm{~g}$ of crude extract, which was solubilized in water $(1 \mathrm{~L})$ and then filtered. The water-insoluble fraction (175 g) was separated on a silica gel column (200-300 mesh, $80 \times 5 \mathrm{~cm}$, i.d.) that was eluted with a gradient of Petroleum ether/Acetone (from 10:1 to 10:5, v/v) to afford seven fractions $1-7$.

Fraction 5 (6 g) was subjected to Sephadex LH-20 column $(120 \times 3 \mathrm{~cm}$, i.d.) eluting with $\mathrm{CHCl}_{3} / \mathrm{MeOH}(1: 1, \mathrm{v} / \mathrm{v})$ to afford five fractions 5-1-5-5. Fraction 5-2 was subjected to chromatography over a silica gel column (silica gel $\mathrm{H}, 25 \times 2.5 \mathrm{~cm}$, i.d.) with a gradient of Petroleum ether/ $\mathrm{CHCl}_{3} /$ EtOAc $(10: 6: 2, \mathrm{v} / \mathrm{v})$ to yield $1(11.0 \mathrm{mg})$. Fraction 5-3 was purified by chromatography over a silica gel column (silica gel $\mathrm{H}, 25 \times 2.5 \mathrm{~cm}$, i.d.) eluting with a gradient of Petroleum ether/Acetone/MeOH (10/20/2, v/v) to afford 2 (15.2 mg), 3 (16.6 mg) and 6 (21.4 mg).

And fraction 7 ( $8 \mathrm{~g})$ was subjected to Sephadex LH-20 column $(120 \times 3 \mathrm{~cm}$, i.d.) chromatography eluting with $\mathrm{MeOH}$ to afford four fractions 7-1-7-4. Fraction 7-4 was then purified by semi-preparative HPLC with a gradient of $\mathrm{CHCl}_{3}-\mathrm{MeOH}(100: 4, \mathrm{v} / \mathrm{v})$ to give $4(7.2 \mathrm{mg})$ and $5(6.3 \mathrm{mg})$.

\subsection{Spectral Data}

Davinvolunol $A$ (1): white amorphous powder; $[\alpha]_{D}^{20}=+99.0$ (c $\left.0.15, \mathrm{CHCl}_{3}\right)$; IR (KBr) vmax: 3560 , 2950, 1640, $1470 \mathrm{~cm}^{-1}$; HR-TOF-MS $m / z=435.3596[\mathrm{M}+\mathrm{Na}]^{+}\left(\right.$calcd for $\left.\mathrm{C}_{29} \mathrm{H}_{48} \mathrm{ONa}, 435.3603\right)$; ${ }^{1} \mathrm{H}-\mathrm{NMR}\left(500 \mathrm{MHz}, \mathrm{CDCl}_{3}\right.$ and $\left.\mathrm{CD}_{3} \mathrm{OD}\right)$ and ${ }^{13} \mathrm{C}-\mathrm{NMR}\left(125 \mathrm{MHz}, \mathrm{CDCl}_{3}\right.$ and $\left.\mathrm{CD}_{3} \mathrm{OD}\right)$ data (Tables 2 and 3). 
Table 2. ${ }^{1} \mathrm{H}-\mathrm{NMR}$ Data of compounds 1-5.

\begin{tabular}{|c|c|c|c|c|c|}
\hline Position & $1^{\mathrm{a}}\left[\delta_{\mathrm{H}}(J\right.$ in $\left.\mathrm{Hz})\right]$ & $2^{\mathrm{b}}\left[\delta_{\mathrm{H}}(J\right.$ in $\left.\mathrm{Hz})\right]$ & $3^{\mathrm{c}}\left[\delta_{\mathrm{H}}(J\right.$ in $\left.\mathrm{Hz})\right]$ & $4^{\mathrm{d}}\left[\delta_{\mathrm{H}}(J\right.$ in $\left.\mathrm{Hz})\right]$ & $5^{\mathrm{d}}\left[\delta_{\mathrm{H}}(J\right.$ in $\left.\mathrm{Hz})\right]$ \\
\hline \multirow{2}{*}{1} & $0.80, \mathrm{~m}$ & $0.84, \mathrm{~m}$ & $1.60, \mathrm{~d}(14.3)$ & $2.05, \mathrm{~m}$ & $1.80, \mathrm{~m}$ \\
\hline & $1.53, \mathrm{~m}$ & $1.51, \mathrm{~m}$ & $1.79, \mathrm{~d}(14.3)$ & $2.12, \mathrm{~m}$ & $1.85, \mathrm{~m}$ \\
\hline \multirow{2}{*}{2} & - & - & - & $2.30, \mathrm{~m}$ & $2.32, \mathrm{~m}$ \\
\hline & - & - & - & $2.75, \operatorname{ddd}(16.3,11.2,4.9)$ & 2.59, ddd $(16.3,11.2,6.4)$ \\
\hline 3 & $\begin{array}{l}2.01, \mathrm{~m} \\
2.25 \mathrm{~m}\end{array}$ & $3.18, \mathrm{dd}(9.8,6.8)$ & - & - & - \\
\hline 4 & - & - & - & - & - \\
\hline 5 & $1.00, \mathrm{~m}$ & $0.98, \mathrm{~m}$ & $1.61, \mathrm{~d}(10.9)$ & $1.78, \mathrm{~d}(11.1)$ & $2.03, \mathrm{~d}(11.0)$ \\
\hline 6 & $\begin{array}{c}1.23, \mathrm{~m} \\
1.83, \mathrm{~d}(13.0)\end{array}$ & $\begin{array}{c}1.21, \mathrm{~m} \\
1.80, \mathrm{~d}(13.0)\end{array}$ & 3.91, ddd $(15.0,10.9,4.1)$ & $3.98, \operatorname{ddd}(15.2,11.1,4.2)$ & 3.98, ddd $(15.2,11.2,4.0)$ \\
\hline \multirow{2}{*}{7} & $1.35, \mathrm{~m}$ & $1.27, \mathrm{~m}$ & $1.38, \mathrm{t}(10.9)$ & $1.49, \mathrm{t}(11.1)$ & $1.50, \mathrm{t}(11.2)$ \\
\hline & 2.03 dt-like (13.0) & $2.01 \mathrm{dt}$-like (13.0) & $2.28, \mathrm{dd}(10.9,4.1)$ & $2.30, \mathrm{dd}(11.1,4.2)$ & $2.28, \mathrm{dd}(11.2,4.0)$ \\
\hline 8 & - & - & - & - & - \\
\hline 9 & $1.49, \mathrm{~m}$ & $1.51, \mathrm{~m}$ & $1.52, \mathrm{~m}$ & $1.60, \mathrm{~d}(7.0)$ & $1.70, \mathrm{~m}$ \\
\hline 10 & - & - & - & - & - \\
\hline \multirow{2}{*}{11} & $1.51, \mathrm{~m}$ & $1.50, \mathrm{~m}$ & $1.60, \mathrm{~m}$ & \multirow{2}{*}{$4.28, \mathrm{t}(7.0)$} & $1.85, \mathrm{~m}$ \\
\hline & $1.65 \mathrm{~m}$ & $1.60, \mathrm{~m}$ & $1.72, \mathrm{~m}$ & & $1.92, \mathrm{~m}$ \\
\hline \multirow{2}{*}{12} & $1.48, \mathrm{~m}$ & $1.46, \mathrm{~m}$ & $1.60, \mathrm{~m}$ & $1.98, \mathrm{~d}(14.5)$ & $1.80, \mathrm{~m}$ \\
\hline & $1.60, \mathrm{~m}$ & $1.53, \mathrm{~m}$ & $1.75, \mathrm{~m}$ & $2.12, \mathrm{~d}(14.5)$ & $1.92, \mathrm{~m}$ \\
\hline 13 & - & - & - & - & - \\
\hline 14 & - & - & - & - & - \\
\hline 15 & $5.51, \mathrm{dd}(8.2,3.1)$ & $5.47, \mathrm{dd}(8.0,3.1)$ & $5.60, \mathrm{dd}(8.1,2.9)$ & 5.96 , br. s & 5.94 , br. s \\
\hline \multirow{2}{*}{16} & $1.68, \mathrm{dd}(15.2,3.1)$ & $1.66, \mathrm{dd}(15.2,3.1)$ & $1.79, \mathrm{dd}(14.5,8.1)$ & & \multirow{2}{*}{ - } \\
\hline & $2.13, \mathrm{dd}(15.2,8.2)$ & $2.09, \mathrm{dd}(15.2,8.0)$ & $2.05, \mathrm{dd}(14.5,2.9)$ & & \\
\hline 17 & - & - & - & - & - \\
\hline 18 & $0.57, \mathrm{dd}(13.5,3.8)$ & $0.60, \mathrm{dd}(13.5,3.8)$ & $1.22, \mathrm{dd}(13.5,5.1)$ & $1.88, \mathrm{dd}(13.5,5.2)$ & $1.92, \mathrm{dd}(13.5,5.1)$ \\
\hline
\end{tabular}


Table 2. Cont.

\begin{tabular}{|c|c|c|c|c|c|}
\hline Position & $1^{\mathrm{a}}\left[\delta_{\mathrm{H}}(J\right.$ in $\left.\mathrm{Hz})\right]$ & $2^{\mathrm{b}}\left[\delta_{\mathrm{H}}(J\right.$ in $\left.\mathrm{Hz})\right]$ & $3^{\mathrm{c}}\left[\delta_{\mathrm{H}}(J\right.$ in $\left.\mathrm{Hz})\right]$ & $4^{\mathrm{d}}\left[\delta_{\mathrm{H}}(J\right.$ in $\left.\mathrm{Hz})\right]$ & $5^{\mathrm{d}}\left[\delta_{\mathrm{H}}(J\right.$ in $\left.\mathrm{Hz})\right]$ \\
\hline \multirow{2}{*}{19} & $0.91, \mathrm{dd}(13.5,3.8)$ & $0.96, \mathrm{dd}(13.5,3.8)$ & $1.44, \mathrm{dd}(13.5,5.1)$ & $1.63, \mathrm{dd}(13.5,5.2)$ & $1.65, \mathrm{dd}(13.5,5.1)$ \\
\hline & $1.37, \mathrm{t}(13.5)$ & $1.32, \mathrm{t}(13.5)$ & $1.88, \mathrm{t}(13.5)$ & $2.54, \mathrm{t}(13.5)$ & $2.49, \mathrm{t}(13.5)$ \\
\hline 20 & - & - & - & - & - \\
\hline \multirow{2}{*}{21} & $1.53, \mathrm{~m}$ & $1.46, \mathrm{~m}$ & \multirow[b]{2}{*}{-} & \multirow[b]{2}{*}{-} & \multirow[b]{2}{*}{-} \\
\hline & $1.65, \mathrm{~m}$ & $1.60, \mathrm{~m}$ & & & \\
\hline \multirow{2}{*}{22} & $1.24, \mathrm{~m}$ & $1.20, \mathrm{~m}$ & $1.87, \mathrm{~d}(12.8)$ & $2.51, \mathrm{~d}(13.8)$ & $2.49, \mathrm{~d}(13.7)$ \\
\hline & $2.05, \mathrm{~m}$ & $2.03, \mathrm{~m}$ & $2.63, \mathrm{~d}(12.8)$ & $2.62, \mathrm{~d}(13.8)$ & $2.61, \mathrm{~d}(13.7)$ \\
\hline \multirow{2}{*}{23} & \multirow{2}{*}{$1.22, \mathrm{~s}$} & \multirow{2}{*}{$1.05, \mathrm{~s}$} & \multirow{2}{*}{$1.29, \mathrm{~s}$} & \multirow{2}{*}{$1.35, \mathrm{~s}$} & $3.58, \mathrm{~d}(10.2)$ \\
\hline & & & & & $3.80, \mathrm{~d}(10.2)$ \\
\hline 24 & $0.94, \mathrm{~s}$ & $0.91, \mathrm{~s}$ & $1.32, \mathrm{~s}$ & $1.36, \mathrm{~s}$ & $1.27, \mathrm{~s}$ \\
\hline 25 & $0.87, \mathrm{~s}$ & $0.84, \mathrm{~s}$ & $0.82, \mathrm{~s}$ & $0.98, \mathrm{~s}$ & $1.13, \mathrm{~s}$ \\
\hline 26 & $1.08, \mathrm{~s}$ & $1.02, \mathrm{~s}$ & $1.11, \mathrm{~s}$ & $1.26, \mathrm{~s}$ & $1.30, \mathrm{~s}$ \\
\hline 27 & $1.07, \mathrm{~s}$ & $1.01, \mathrm{~s}$ & $1.02, \mathrm{~s}$ & $1.22, \mathrm{~s}$ & $0.96, \mathrm{~s}$ \\
\hline \multirow{2}{*}{28} & $3.10(\mathrm{~d}, 10.9)$ & $3.06(\mathrm{~d}, 10.9)$ & \multirow{2}{*}{$0.78, \mathrm{~s}$} & \multirow{2}{*}{$1.07, \mathrm{~s}$} & \multirow{2}{*}{$1.06, \mathrm{~s}$} \\
\hline & $3.23,(\mathrm{~d}, 10.9)$ & $3.18,(\mathrm{~d}, 10.9)$ & & & \\
\hline \multirow{2}{*}{29} & \multirow{2}{*}{$1.05, \mathrm{~s}$} & \multirow{2}{*}{$1.02, \mathrm{~s}$} & \multirow{2}{*}{$1.06, \mathrm{~s}$} & $3.26, \mathrm{~d}(10.3)$ & $3.24, \mathrm{~d}(10.4)$ \\
\hline & & & & $3.71, \mathrm{~d}(10.3)$ & $3.69, \mathrm{~d}(10.4)$ \\
\hline 30 & $0.94, \mathrm{~s}$ & $0.90, \mathrm{~s}$ & $1.05, \mathrm{~s}$ & $1.06, \mathrm{~s}$ & $1.05, \mathrm{~s}$ \\
\hline
\end{tabular}

a Recorded in $\mathrm{CDCl}_{3}$ and $\mathrm{CD}_{3} \mathrm{OD}(10: 1)$ in $500 \mathrm{MHz} ;{ }^{\mathrm{b}}$ Recorded in $\mathrm{CDCl}_{3}$ and $\mathrm{CD}_{3} \mathrm{OD}(10: 1)$ in $400 \mathrm{MHz} ;{ }^{\mathrm{c}}$ Recorded in $\mathrm{CDCl}_{3}$ in $400 \mathrm{MH} ;{ }^{\mathrm{d}}$ Recorded in $\mathrm{CD}_{3} \mathrm{OD}$ in $400 \mathrm{MHz}$.

Table 3. ${ }^{13} \mathrm{C}-\mathrm{NMR}$ Data of compounds $\mathbf{1}-\mathbf{5}$.

\begin{tabular}{cccccc}
\hline Position & $\mathbf{1}^{\mathbf{a}}\left(\boldsymbol{\delta}_{\mathbf{c}}\right.$ mult.) & $\mathbf{2}^{\mathbf{b}}\left(\boldsymbol{\delta}_{\mathbf{c}}\right.$ mult. $)$ & $\mathbf{3}^{\mathbf{c}}\left(\boldsymbol{\delta}_{\mathbf{c}}\right.$ mult. $)$ & $\mathbf{4}^{\text {d }}\left(\boldsymbol{\delta}_{\mathbf{c}}\right.$ mult. $)$ & $\mathbf{5}^{\mathbf{e}}\left(\boldsymbol{\delta}_{\mathbf{c}}\right.$ mult. $)$ \\
\hline 1 & $38.2\left(\mathrm{CH}_{2}\right)$ & $38.1\left(\mathrm{CH}_{2}\right)$ & $37.3\left(\mathrm{CH}_{2}\right)$ & $39.3\left(\mathrm{CH}_{2}\right)$ & $36.4\left(\mathrm{CH}_{2}\right)$ \\
2 & - & - & - & $34.1\left(\mathrm{CH}_{2}\right)$ & $31.6\left(\mathrm{CH}_{2}\right)$ \\
3 & $29.8\left(\mathrm{CH}_{2}\right)$ & $77.3(\mathrm{CH})$ & $219.7(\mathrm{C})$ & $222.5(\mathrm{C})$ & $220.9(\mathrm{C})$ \\
4 & $47.5(\mathrm{C})$ & $47.7(\mathrm{C})$ & $47.0(\mathrm{C})$ & $49.2(\mathrm{C})$ & $54.3(\mathrm{C})$ \\
\hline
\end{tabular}


Table 3. Cont.

\begin{tabular}{|c|c|c|c|c|c|}
\hline Position & $1^{\mathrm{a}}\left(\delta_{\mathrm{c}}\right.$ mult. $)$ & $2^{\mathrm{b}}\left(\delta_{\mathrm{c}}\right.$ mult. $)$ & $3^{c}\left(\delta_{c}\right.$ mult. $)$ & $4^{\mathrm{d}}\left(\delta_{\mathrm{c}}\right.$ mult. $)$ & $5^{\mathrm{e}}\left(\delta_{\mathrm{c}}\right.$ mult. $)$ \\
\hline 5 & $55.7(\mathrm{CH})$ & $55.7(\mathrm{CH})$ & $58.8(\mathrm{CH})$ & $59.9(\mathrm{CH})$ & $54.2(\mathrm{CH})$ \\
\hline 6 & $19.9\left(\mathrm{CH}_{2}\right)$ & $19.8\left(\mathrm{CH}_{2}\right)$ & $67.3(\mathrm{CH})$ & $67.5(\mathrm{CH})$ & $67.2(\mathrm{CH})$ \\
\hline 7 & $40.6\left(\mathrm{CH}_{2}\right)$ & $40.5\left(\mathrm{CH}_{2}\right)$ & $50.4\left(\mathrm{CH}_{2}\right)$ & $50.2\left(\mathrm{CH}_{2}\right)$ & $50.3\left(\mathrm{CH}_{2}\right)$ \\
\hline 8 & $38.9(\mathrm{C})$ & $38.9(\mathrm{C})$ & $39.7(\mathrm{C})$ & $41.2(\mathrm{C})$ & $42.5(\mathrm{C})$ \\
\hline 9 & $48.5(\mathrm{CH})$ & $48.5(\mathrm{CH})$ & $47.0(\mathrm{CH})$ & $55.9(\mathrm{CH})$ & $47.2(\mathrm{CH})$ \\
\hline 10 & $40.3(\mathrm{C})$ & $40.3(\mathrm{C})$ & $38.5(\mathrm{C})$ & $40.7(\mathrm{C})$ & $40.0(\mathrm{C})$ \\
\hline 11 & $17.3\left(\mathrm{CH}_{2}\right)$ & $17.2\left(\mathrm{CH}_{2}\right)$ & $16.8\left(\mathrm{CH}_{2}\right)$ & $65.9(\mathrm{CH})$ & $17.7\left(\mathrm{CH}_{2}\right)$ \\
\hline 12 & $30.6\left(\mathrm{CH}_{2}\right)$ & $30.5\left(\mathrm{CH}_{2}\right)$ & $33.2\left(\mathrm{CH}_{2}\right)$ & $43.3\left(\mathrm{CH}_{2}\right)$ & $37.4\left(\mathrm{CH}_{2}\right)$ \\
\hline 13 & $37.6(\mathrm{C})$ & $37.6(\mathrm{C})$ & $37.3(\mathrm{C})$ & $38.9(\mathrm{C})$ & $39.3(\mathrm{C})$ \\
\hline 14 & $158.5(\mathrm{C})$ & $158.3(\mathrm{C})$ & $157.3(\mathrm{C})$ & $177.9(\mathrm{C})$ & $178.3(\mathrm{C})$ \\
\hline 15 & $116.0(\mathrm{CH})$ & $116.1(\mathrm{CH})$ & $116.5(\mathrm{CH})$ & $118.8(\mathrm{CH})$ & $119.4(\mathrm{CH})$ \\
\hline 16 & $32.6\left(\mathrm{CH}_{2}\right)$ & $32.5\left(\mathrm{CH}_{2}\right)$ & $37.5\left(\mathrm{CH}_{2}\right)$ & $206.3(\mathrm{C})$ & 206.3 (C) \\
\hline 17 & $37.9(\mathrm{C})$ & $37.9(\mathrm{C})$ & $37.3(\mathrm{C})$ & $47.1(\mathrm{C})$ & $47.2(\mathrm{C})$ \\
\hline 18 & $44.8(\mathrm{CH})$ & $44.7(\mathrm{CH})$ & $48.8(\mathrm{CH}$ & $46.4(\mathrm{CH})$ & $46.7(\mathrm{CH})$ \\
\hline 19 & $35.7\left(\mathrm{CH}_{2}\right)$ & $35.7\left(\mathrm{CH}_{2}\right)$ & $37.3\left(\mathrm{CH}_{2}\right.$ & $31.4\left(\mathrm{CH}_{2}\right)$ & $31.8\left(\mathrm{CH}_{2}\right)$ \\
\hline 20 & $28.9(\mathrm{C})$ & $28.8(\mathrm{C})$ & $43.1(\mathrm{C})$ & $48.7(\mathrm{C})$ & $48.5(\mathrm{C})$ \\
\hline 21 & $33.3\left(\mathrm{CH}_{2}\right)$ & $33.2\left(\mathrm{CH}_{2}\right)$ & $219.7(\mathrm{C})$ & $219.9(\mathrm{C})$ & $220.0(\mathrm{C})$ \\
\hline 22 & $27.8\left(\mathrm{CH}_{2}\right)$ & $27.6\left(\mathrm{CH}_{2}\right)$ & $51.5\left(\mathrm{CH}_{2}\right)$ & $48.4\left(\mathrm{CH}_{2}\right)$ & $48.2\left(\mathrm{CH}_{2}\right)$ \\
\hline 23 & $25.6\left(\mathrm{CH}_{3}\right)$ & $25.9\left(\mathrm{CH}_{3}\right)$ & $31.5\left(\mathrm{CH}_{3}\right)$ & $32.2\left(\mathrm{CH}_{3}\right)$ & $72.5\left(\mathrm{CH}_{2}\right)$ \\
\hline 24 & $21.3\left(\mathrm{CH}_{3}\right)$ & $21.3\left(\mathrm{CH}_{3}\right)$ & $19.7\left(\mathrm{CH}_{3}\right)$ & $20.6\left(\mathrm{CH}_{3}\right)$ & $16.4\left(\mathrm{CH}_{3}\right)$ \\
\hline 25 & $14.7\left(\mathrm{CH}_{3}\right)$ & $14.7\left(\mathrm{CH}_{3}\right)$ & $16.0\left(\mathrm{CH}_{3}\right)$ & $17.9\left(\mathrm{CH}_{3}\right)$ & $17.1\left(\mathrm{CH}_{3}\right)$ \\
\hline 26 & $25.7\left(\mathrm{CH}_{3}\right)$ & $25.7\left(\mathrm{CH}_{3}\right)$ & $25.6\left(\mathrm{CH}_{3}\right)$ & $25.5\left(\mathrm{CH}_{3}\right)$ & $24.6\left(\mathrm{CH}_{3}\right)$ \\
\hline 27 & $21.6\left(\mathrm{CH}_{3}\right)$ & $21.5\left(\mathrm{CH}_{3}\right)$ & $20.2\left(\mathrm{CH}_{3}\right)$ & $29.1\left(\mathrm{CH}_{3}\right)$ & $26.9\left(\mathrm{CH}_{3}\right)$ \\
\hline 28 & $65.1\left(\mathrm{CH}_{2}\right)$ & $64.7\left(\mathrm{CH}_{2}\right)$ & $32.5\left(\mathrm{CH}_{3}\right)$ & $33.8\left(\mathrm{CH}_{3}\right)$ & $33.9\left(\mathrm{CH}_{3}\right)$ \\
\hline 29 & $33.4\left(\mathrm{CH}_{3}\right)$ & $33.3\left(\mathrm{CH}_{3}\right)$ & $28.1\left(\mathrm{CH}_{3}\right)$ & $71.2\left(\mathrm{CH}_{2}\right)$ & $71.2\left(\mathrm{CH}_{2}\right)$ \\
\hline 30 & $29.8\left(\mathrm{CH}_{3}\right)$ & $29.7\left(\mathrm{CH}_{3}\right)$ & $23.0\left(\mathrm{CH}_{3}\right)$ & $20.2\left(\mathrm{CH}_{3}\right)$ & $20.2\left(\mathrm{CH}_{3}\right)$ \\
\hline
\end{tabular}

${ }^{a}$ Recorded in $\mathrm{CDCl}_{3}$ and $\mathrm{CD}_{3} \mathrm{OD}(10: 1)$ in $125 \mathrm{MHz} ;{ }^{\mathrm{b}}$ Recorded in $\mathrm{CDCl}_{3}$ and $\mathrm{CD}_{3} \mathrm{OD}$ (10:1) in $100 \mathrm{MHz} ;{ }^{\mathrm{c}}$ Recorded in $\mathrm{CDCl}_{3}$ in $100 \mathrm{MHz} ;{ }^{\mathrm{d}} \mathrm{Recorded}$ in $\mathrm{CD}_{3} \mathrm{OD}$ in $100 \mathrm{MH} ;{ }^{\mathrm{e}}$ Recorded in $\mathrm{CD}_{3} \mathrm{OD}$ in $125 \mathrm{MHz}$. 
Davinvolunol B (2): white amorphous powder; $[\alpha]_{D}^{20}=+104.5\left(\right.$ c $\left.0.17, \mathrm{CHCl}_{3}\right)$; IR ( $\left.\mathrm{KBr}\right) v_{\max }$ : 3500, 2920, 1640, $1470 \mathrm{~cm}^{-1}$; HR-TOF-MS $\mathrm{m} / z=451.3546[\mathrm{M}+\mathrm{Na}]^{+}$(calcd for $\mathrm{C}_{29} \mathrm{H}_{48} \mathrm{O}_{2} \mathrm{Na}, 451.3552$ ); ${ }^{1} \mathrm{H}-\mathrm{NMR}\left(400 \mathrm{MHz}, \mathrm{CDCl}_{3}\right.$ and $\left.\mathrm{CD}_{3} \mathrm{OD}\right)$ and ${ }^{13} \mathrm{C}-\mathrm{NMR}\left(100 \mathrm{MHz}, \mathrm{CDCl}_{3}\right.$ and $\left.\mathrm{CD}_{3} \mathrm{OD}\right)$ data (Tables 2 and 3).

Davinvolunone $A(3)$ : white amorphous powder; $[\alpha]_{D}^{20}=+116.8$ (c 0.16, $\mathrm{CHCl}_{3}$ ); IR (KBr) vmax: 3437, 2930, 1726, 1635, $1456 \mathrm{~cm}^{-1}$; HR-TOF-MS $\mathrm{m} / \mathrm{z} 463.3180[\mathrm{M}+\mathrm{Na}]^{+}$(calcd for $\mathrm{C}_{29} \mathrm{H}_{44} \mathrm{O}_{3} \mathrm{Na}$, 463.3188); ${ }^{1} \mathrm{H}-\mathrm{NMR}\left(400 \mathrm{MHz}, \mathrm{CDCl}_{3}\right)$ and ${ }^{13} \mathrm{C}-\mathrm{NMR}\left(100 \mathrm{MHz}, \mathrm{CDCl}_{3}\right)$ data (Tables 2 and 3$)$.

Davinvolunone $B(4)$ : white amorphous powder; $[\alpha]_{D}^{20}=+126.0$ (c 0.12, $\mathrm{CHCl}_{3}$ ); IR ( $\left.\mathrm{KBr}\right) v_{\max }$ : 3500, 2930, 1700, 1610, $1456 \mathrm{~cm}^{-1}$; HR-TOF-MS m/z 523.3030 $[\mathrm{M}+\mathrm{Na}]^{+}$(calcd for $\mathrm{C}_{30} \mathrm{H}_{44} \mathrm{O}_{6} \mathrm{Na}$, 523.3036); ${ }^{1} \mathrm{H}-\mathrm{NMR}\left(400 \mathrm{MHz}, \mathrm{CD}_{3} \mathrm{OD}\right)$ and ${ }^{13} \mathrm{C}-\mathrm{NMR}\left(100 \mathrm{MHz}, \mathrm{CD}_{3} \mathrm{OD}\right)$ data (Tables 2 and 3).

Davinvolunone $C$ (5): white amorphous powder; $[\alpha]_{D}^{20}=+118.2\left(\right.$ c $\left.0.20, \mathrm{CHCl}_{3}\right)$; IR ( $\left.\mathrm{KBr}\right) v_{\max }$ : 3489, 2920, 1700, 1610, $1453 \mathrm{~cm}^{-1}$; HR-TOF-MS m/z 523.3030 $[\mathrm{M}+\mathrm{Na}]^{+}$(calcd for $\mathrm{C}_{30} \mathrm{H}_{44} \mathrm{O}_{6} \mathrm{Na}$, 523.3036); ${ }^{1} \mathrm{H}-\mathrm{NMR}\left(400 \mathrm{MHz}, \mathrm{CD}_{3} \mathrm{OD}\right)$ and ${ }^{13} \mathrm{C}-\mathrm{NMR}\left(125 \mathrm{MHz}, \mathrm{CD}_{3} \mathrm{OD}\right)$ data (Tables 2 and 3).

\subsection{Cytotoxicity Assay}

The in vitro cytotoxic activity was determined by the MTT colorimetric method as described previously in our paper [13]. Three tumor cell lines, SGC-7901 cells (human gastric adenocarcinoma), MCF-7 cells (human breast cancer) and BEL-7404 (human hepatocellular carcinoma), provided by Department of Hepatobiliary Surgery, Affiliated Union Hospital, Fujian Medical University, were cultured in RPMI-1640 medium supplemented with $10 \%$ fetal bovine serum and $100 \mathrm{IU} \cdot \mathrm{mL}^{-1}$ of penicillin-streptomycin at $37{ }^{\circ} \mathrm{C}$ in humidified atmosphere with $5 \% \mathrm{CO}_{2}$. For the cytotoxicity tests, cells in exponential growth stage were harvested from culture by trypsin digestion and centrifuging at $180 \times \mathrm{g}$ for $3 \mathrm{~min}$, and then resuspended in fresh medium at a cell density of $5 \times 104$ per $\mathrm{mL}$. The cell suspension was dispensed into a 96-well microplate at $100 \mu \mathrm{L}$ and incubated for $24 \mathrm{~h}$, and then treated with compounds at various concentrations. After $48 \mathrm{~h}$ of treatment, $50 \mu \mathrm{L}$ solution of $1 \mathrm{mg} \cdot \mathrm{mL}^{-1} \mathrm{MTT}$ was added to each well, and the cells were further incubated for $4 \mathrm{~h}$. Finally, supernatants were removed and the formazan crystals were dissolved by adding $100 \mu \mathrm{L}$ DMSO and the optical density was recorded at $570 \mathrm{~nm}$. All drug doses were tested with doxorubicin as positive control in triplicate.

\section{Conclusions}

The phytochemical study of the methanol extract from the branch barks of Davidia involucrata has led to the isolation of five new taraxerene-type triterpenes, namely 2-nor-D-friedoolean-14-en-28-ol

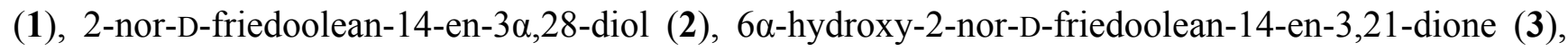
$6 \alpha, 11 \alpha, 29$-trihydroxy-D-friedoolean-14-en-3,16,21-trione (4), and 6a,23,29-trihydroxy-D-friedoolean14-en-3,16,21-trione (5), in addition to five known compounds. This is the first report of the isolation of taraxerene-type triterpenes from the plant, and compounds 1-3 are rarely reported 2-nor pentacyclic triterpenoids with 29 carbons and a five-membered A-ring. Our studies suggested that pure triterpenoids isolated from the relic deciduous plant demonstrated moderate cytotoxic activities against the proliferation of SGC-7901, MCF-7, and BEL-7404 cell lines. 


\section{Supplementary Materials}

Supplementary materials can be accessed at: http:/www.mdpi.com/1420-3049/19/11/17619/s1.

\section{Acknowledgments}

Financial support from National Science and Technology Major Project (Grant No. 2011AA10A203, and 2012BAD19B03), National Natural Science Foundation of China (Grant No. 31371987), Chinese Ministry of Education (Grant No. 20103515110007), Fujian Provincial Department of Science and Technology Major Project (Grant No. 2012N4001), Natural Science Foundation of Fujian Province (Grant No. 2013J05046), Fujian Provincial Department of Education (Grant No. JA12125) is gratefully acknowledged.

\section{Author Contributions}

Qing-Wei Tan took charge of the isolation, purification and structure elucidation of the isolated compounds. Ming-An Ouyang participated in the structure elucidation of the isolated compounds. Qi-Jian Chen and Zu-Jian Wu were responsible for the cytotoxicity assay.

\section{Conflicts of Interest}

The authors declare no conflict of interest.

\section{References}

1. Li, Y.X.; Chen, L.; Lin, J.; Li, Y.F.; Chen, F. Suppression subtractive hybridization cloning of cDNAs of differentially expressed genes in dovetree (Davidia involucrata) bracts. Plant Mol. Biol. Rep. 2002, 20, 231-238.

2. Sun, J.F.; Huang, S.Q. White bracts of the Dove Tree (Davidia involucrata): Umbrella and pollinator lure? Mag. Arnold Arboretum 2011, 68, 2-10.

3. Sun, J.F.; Gong, Y.B.; Renner, S.S.; Huang, S.Q. Multifunctional bracts in the Dove Tree Davidia involucrata (Nyssaceae: Cornales). Rain protection and pollinator attraction. Am. Nat. 2008, 171, 119-124.

4. Xiang, G.Q.; Lu, F.S. Study on chemical components of Davidia involucrata Baill. native to China. Acta Bot. Sin. 1989, 31, 540-543.

5. Ouyang, M.A.; Zhou, J.N. Flavonoid glycosides from the leaves of Davidia involucrata. Guihaia 2003, 23, 568-570.

6. Huang, J.; Liu, R.; Wang, C.Z.; Ouyang, M.A. Progress in study on chemical constituents of Nyssaceae family. Subtrop. Plant Sci. 2005, 34, 70-75.

7. Liu, R.; Ouyang, M.A. Structural identification of pumiloside, a quinolone alkaloid glycoside isolated from leaves of Davidia involucrata. Subtrop. Plant Sci. 2006, 35, 35-38.

8. Liu, R.; Wang, C.Z.; Ouyang, M.A. Studies on the alkaloid glycoside constituents from branch-bark of Davidia involucrata. Guihaia 2007, 27, 277-280. 
9. Ouyang, M.A.; Huang, J.; Tan, Q.W. Neolignan and lignan glycosides from branch bark of Davidia involucrata. J. Asian Nat. Prod. Res. 2007, 9, 487-492.

10. Ouyang, M.A.; Zhou, J.N.; Wang, S.B. New caffeoyl derivatives from the leaves of Davidia involucrata. Nat. Prod. Res. 2008, 22, 471-476.

11. Wu, Z.J.; Ouyang, M.A.; Wang, S.B. Two new phenolic water-soluble constituents from branch bark of Davidia involucrata. Nat. Prod. Res. 2008, 22, 483-488.

12. Sirikantaramas, S.; Asano, T.; Sudo, H.; Yamazaki, M.; Saito, K. Camptothecin: Therapeutic potential and biotechnology. Curr. Pharm. Biotechnol. 2007, 8, 196-202.

13. Tan, Q.W.; Ouyang, M.A.; Gao, B. Three new ring-A modified ursane triterpenes from Davidia involucrata. Molecules 2014, 19, 4897-4906.

14. Kerr, P.G.; Longmore, R.B.; Betts, T.J. Myricadiol and other taraxerenes from Scaevola spinescens. Planta Med. 1996, 62, 519-522.

15. Merfort, I.; Buddrus, J.; Nawwar, M.A.M.; Lambert, J. A triterpene from the bark of Tamarix aphylla. Phytochemistry 1992, 31, 4031-4032.

16. Sakurai, N.; Yaguchi, Y.; Inoue, T. Triterpenoids from Myrica rubra. Phytochemistry 1986, 26, 217-219.

17. Ogura, M.; Cordell, G.A.; Farnsworth, N.R. Jacoumaric acid, a new triterpene ester from Jacaranda caucana. Phytochemistry 1977, 16, 286-287.

18. Wang, Q.; Ju, P.; Wang, Y.F.; Luo, S.D. Triterpenoids from Saurauia napaulensis (Saurauiaceae). Acta Bot. Yunnanica 2008, 30, 121-124.

19. Häberlein H.; Tschiersch, K.P. Triterpenoids and flavonoids from Leptospermum scoparium. Phytochemistry 1994, 35, 765-768.

Sample Availability: Samples of the compounds 1-7 are available from the authors.

(C) 2014 by the authors; licensee MDPI, Basel, Switzerland. This article is an open access article distributed under the terms and conditions of the Creative Commons Attribution license (http://creativecommons.org/licenses/by/4.0/). 